\title{
Intermittent drying of clove basil leaves: Process optimization and essential oil yield
}

\author{
Raiane A. de Souza ${ }^{1}$, Evandro de C. Melo ${ }^{1}$, Mariane B. R. de Ávila ${ }^{1}$, Diego A. Gonzaga ${ }^{1}$, \\ Naiara C. Z. Sperotto ${ }^{1} \&$ Antônio P. S. Carneiro ${ }^{2}$ \\ ${ }^{1}$ Universidade Federal de Viçosa/Departamento de Engenharia Agrícola, Viçosa, MG, Brasil. E-mail: raisouza324@gmail.com (Corresponding \\ author) - ORCID: 0000-0003-0333-8958; evandro@ufv.br - ORCID: 0000-0002-1418-8345; avilanane@gmail.com - ORCID: 0000-0001-6161-977X; \\ gonzagaaugusto@gmail.com - ORCID: 0000-0001-6242-3453; naiazotti@gmail.com - ORCID: 0000-0003-4536-6850 \\ ${ }^{2}$ Universidade Federal de Viçosa/Departamento de Estatística, Viçosa, MG, Brasil. E-mail: policarpo@ufv.br - ORCID: 0000-0002-9043-3242
}

\begin{abstract}
This study investigated the effect of a drying method with intermittent ratios on the effective drying time, specific energy consumption and essential oil yield of clove basil (Ocimum gratissimum L.) leaves. The drying tests were conducted at the Postharvest Laboratory of Medicinal, Aromatic and Condiment Plants, from the Departamento de Engenharia Agrícola of the Universidade Federal de Viçosa, Viçosa, MG, Brazil $\left(20^{\circ} 46^{\prime} 13.5^{\prime \prime} \mathrm{S} ; 42^{\circ} 52^{\prime} 23.3^{\prime \prime} \mathrm{W}\right.$, and altitude of $\left.645 \mathrm{~m}\right)$ in October and November 2017. The experiment was conducted by using a $3 \times 4$ factorial scheme including three drying temperatures at 50,60 and $70{ }^{\circ} \mathrm{C}$, with four drying processes: continuous drying and the following three intermittent drying/tempering ratios in minutes: $10 / 20,15 / 15$ and 20/10. The design was completely randomized and with three repetitions. The application of the 10/20 intermittent ratio reduced the effective drying time and the specific energy consumption. Regarding the essential oil yield, the use of the intermittence presented different results for each temperature of drying; the highest yields were observed with continuous drying at $50^{\circ} \mathrm{C}$ and drying with the $20 / 10$ intermittent ratio at $60^{\circ} \mathrm{C}$. The results indicate that intermittent drying at $50^{\circ} \mathrm{C}$ is not recommended to preserve essential oil yields.
\end{abstract}

Key words: Ocimum gratissimum L., medicinal plant, tempering time, effective drying time, specific energy consumption

\section{Secagem intermitente de folhas de manjericão cravo: Otimização do processo e rendimento de óleo essencial}

RESUMO: Este estudo investigou o efeito de um método de secagem com razões intermitentes no tempo efetivo de secagem, consumo específico de energia e rendimento de óleo essencial de folhas de manjericão cravo (Ocimum gratissimum L.). Os testes de secagem foram conduzidos no Laboratório de Pós-colheita de Plantas Medicinais, Aromáticas e Condimentares do Departamento de Engenharia Agrícola da Universidade Federal de Viçosa, Viçosa, MG, (20 $46^{\prime} 13.5^{\prime \prime} \mathrm{S} ; 42^{\circ} 52^{\prime} 23.3^{\prime \prime} \mathrm{N}$, e altitude de $\left.665 \mathrm{~m}\right)$ em outubro e novembro de 2017. O experimento foi conduzido usando um esquema fatorial $3 \times 4$, incluindo três temperaturas de secagem a 50, 60 e $70^{\circ} \mathrm{C}$, com quatro processos de secagem: contínua e as três razões intermitentes seguintes de secagem/repouso em minutos 10/20, 15/15 e 20/10. O delineamento foi inteiramente casualizado e com três repetições. A aplicação da razão intermitente 10/20 reduziu o tempo efetivo de secagem e o consumo específico de energia. Quanto ao rendimento de óleo essencial, o uso da intermitência apresentou resultados diferentes para cada temperatura de secagem; os maiores rendimentos foram observados com secagem contínua a $50{ }^{\circ} \mathrm{C}$ e secagem com a razão intermitente $20 / 10$ a $60^{\circ} \mathrm{C}$. Os resultados indicam que a secagem intermitente a $50^{\circ} \mathrm{C}$ não é recomendada para preservar o rendimento de óleo essencial.

Palavras-chave: Ocimum gratissimum L., planta medicinal, tempo de repouso, tempo efetivo de secagem, consumo específico de energia 


\section{INTRODUCTION}

The clove basil (Ocimum gratissimum L.) species, belonging to the family Lamiacea, is used in popular medicine for the treatment of several ailments such as respiratory disease, skin disease, diarrhea and conjunctivitis (Onajobi, 1986). The therapeutic effect of O. gratissimum is provided by compounds present in its essential oil and extracts that provide antimicrobial (Prakash et al., 2011), antioxidant (Saeio et al., 2011), antinociceptive (Paula-Freire et al., 2013) and antidiabetic (Okoduwa et al., 2017) benefits.

Medicinal plants used as raw materials for the pharmaceutical industry and as teas by consumers should be stored (Marchese \& Figueira, 2005). Drying is the most appropriate operation for quality preservation (Goneli et al., 2014). However, most medicinal plant species contain heat-sensitive cell structures and compounds; the drying process can cause thermal damage and degradation or volatilization of the active ingredients of medicinal interest (Esturk, 2012; Chakraborty \& Dey, 2016; Gasparin et al., 2017).

To address this problem, intermittent drying is an option whereby periods of constant drying are alternated with tempering periods (Kumar et al., 2014). During the tempering period, the water moves from the center to the surface of the product, which facilitating its removal with the resumption of the drying process (Kumar et al., 2014). By using this process, product quality standards such as color, texture and nutrient content are maintained, and the drying time and energy expenditure are reduced (Kowalski et al., 2011; Putranto et al., 2011).

Research evaluating the influence of intermittent drying on the quality of medicinal plants is incipient. Therefore, the objective of the present study is to evaluate the effect of a drying method with intermittent ratios on the effective drying time, specific energy consumption and essential oil yield of clove basil leaves.

\section{Material ANd Methods}

In this study, leaves of Ocimum gratissimum L. (exsicata: PAMG 57974; SISGEN registration A2B5AFE) were used, obtained from organic cultivation in the experimental area of the Departamento de Engenharia Agrícola of the Universidade Federal de Viçosa, Viçosa, MG, Brazil (2046’ 13,5” S; $42^{\circ} 52^{\prime}$ $23,3^{\prime \prime} \mathrm{W}$, and altitude of $665 \mathrm{~m}$ ). The leaves were harvested in October and November 2017 in the morning between 08:00 and 09:00 local time. For better conservation, the leaves were harvested with the stems and were taken to the Postharvest Laboratory of Medicinal, Aromatic and Condiment Plants, where they were packed in black polyethylene bags and stored in a refrigerator at a temperature of $5 \pm 1^{\circ} \mathrm{C}$ up to the maximum of 3 days, period defined by preliminary tests.

Determination of the moisture content of the fresh leaves was performed immediately after each harvest following the methodology adapted from the Brazilian Pharmacopoeia (Brasil, 2010). To achieve this, a sample of approximately $10 \mathrm{~g}$ of fresh leaves was dried in an oven with forced air circulation (CE-220/150, Cienlab Equipamentos Científicos Ltda,
Campinas, SP, Brazil) at a temperature of $105 \pm 2{ }^{\circ} \mathrm{C}$ until it reached constant mass. The tests were performed in triplicate.

The drying tests were conducted at the Postharvest Laboratory of Medicinal, Aromatic and Condiment Plants by using three fixed-bed dryers with ascending air flow. The air in each dryer was heated using a $7.5 \mathrm{~kW}$ electric resistance system, and the air was moved using a $48 \mathrm{~W}$ axial fan. The temperature was controlled by an automatic system. The dryer air speed was regulated manually and was measured by using a digital anemometer (AVM/07, Prova Instruments, Inc., Taiwan) having a reading range of $0.05-25 \mathrm{~m} \mathrm{~s}^{-1}$ and a sensitivity of $0.01 \mathrm{~m} \mathrm{~s}^{-1}$.

Before to each drying test, defoliation of the stored plant material was performed wherein any damaged or diseased leaves and foreign material present were discarded. The material was subsequently homogenized and weighed by using a precision analytical balance (Mark 4100, BEL Engineering, Monza, Milan, Italy). Each replicate contained about $270 \mathrm{~g}$ of fresh O. gratissimum leaves.

Afterward, the samples were submitted to continuous and intermittent drying processes with air temperatures of 50, 60 and $70{ }^{\circ} \mathrm{C}$ and an air velocity of $1.00 \mathrm{~m} \mathrm{~s}^{-1}$. The variables including the intermittent ratios, defined by preliminary testing, are described below.

a) Continuous drying of O. gratissimum L. leaves until a predetermined water content was reached.

b) Intermittent drying at a drying/tempering ratio of 10/20, where the numbers indicate the duration of each interval in minutes.

c) Intermittent drying at a drying/tempering ratio of $15 / 15$.

d) Intermittent drying at a drying/tempering ratio of 20/10.

The tempering period began when the samples were removed from the dryer, which interrupted their exposure to the heated air.

During the drying period, weight measurement was conducted in $5 \mathrm{~min}$ intervals to determine the loss of moisture in the samples. At each weighing, data of the ambient air, including temperature and air relative humidity, were obtained by using a digital thermohygrometer (HOBO U14001, Onset Computer Corp., Bourne, Massachusetts, United States). The drying process was terminated when the product reached its final mass corresponding to a moisture content of approximately $11 \%$ (d.b.).

After drying, the dried leaves were packed in $30 \times 40 \times$ 0.10 low-density polyethylene (LDPE) packages, wrapped in kraft paper bags, and identified before being stored at room temperature until the essential oil was extracted.

The energy consumption during the drying process in each treatment was estimated by using Eq. 1:

$$
\mathrm{EC}=\left[\left(\mathrm{V}_{\mathrm{ar}} \rho_{\mathrm{ar}} \mathrm{Cp}_{\mathrm{ar}} \Delta \mathrm{T}\right)+\mathrm{Ef}\right] \mathrm{tdr}
$$

where:

EC - energy consumed, $\mathrm{kJ}$;

$\mathrm{V}_{\mathrm{ar}} \quad$ - air flow, $\mathrm{m}^{3} \mathrm{~s}^{-1}$;

$\rho_{\mathrm{ar}} \quad$ - specific mass of the air, $\mathrm{kg} \mathrm{m}^{-3}$;

$\mathrm{Cp}_{\mathrm{ar}}$ - specific heat of the air at constant pressure, $\mathrm{kJ} \mathrm{kg}^{-1}{ }^{\circ} \mathrm{K}^{-1}$;

$\Delta \mathrm{T}$ - temperature difference between the drying air and ambient air, K; 
Ef - energy spent to move the fan, $0.048 \mathrm{~kJ} \mathrm{~s}^{-1}$; and, $\mathrm{tdr}$ - effective operating time of the dryer, $\mathrm{s}$.

Specific energy consumption, or the amount of energy required to evaporate a unit of the product's water mass, was obtained by using Eq. 2:

$$
\mathrm{SEC}=\frac{\mathrm{EC}}{\mathrm{m}_{\mathrm{WR}}}
$$

where:

SEC - specific energy consumption, $\mathrm{MJ} \mathrm{kg}^{-1}$ of evaporated water;

EC - energy consumption, MJ; and,

$\mathrm{m}_{\mathrm{WR}}$ - mass of water removed, $\mathrm{kg}$.

The hydrodistillation method was employed to extract the essential oil from the dry leaf samples of O. gratissimum by using a Clevenger apparatus (MA 553/2000, Marconi Equipamentos para Laboratórios Ltda., Piracicaba, SP, Brazil) adapted to a volumetric round bottom flask with a capacity of $2 \mathrm{~L}$. At each extraction, $50 \mathrm{~g}$ of dried leaves and $1 \mathrm{~L}$ of distilled water were added to the flask. The extraction time was 150 min, which was counted at the start of boiling. The yield of extracted essential oil was measured by weighing the vials containing the oil using an analytical balance (M214A, BEL Engineering, Monza, Milan, Italy) with an accuracy of 0.0001 g. The results are expressed as a percentage of oil in relation to the dry matter of the product (\% d.m.).

The experiment was conducted by using a $3 \times 4$ factorial scheme with drying temperatures of 50,60 and $70{ }^{\circ} \mathrm{C}$ including continuous drying and three intermittent ratios of $10 / 20$, $15 / 15$ and 20/10 in a completely randomized design with three repetitions each, totaling 36 experimental units. The results were submitted to analysis of variance (ANOVA), and the means of the processes were compared by applying Tukey's test at $\mathrm{p} \leq 0.05$. The drying air temperature was analyzed by regression. All statistical analyzes were performed using SAS version 9.4 software (SAS Institute, Inc., Cary, North Carolina, United States).

\section{Results AND Discussion}

The initial moisture content of the O. gratissimum leaves used in the drying processes varied between 79.13 and $82.13 \%$. Previous research of the same species reported initial moisture content values of $76.50 \%$ (Luz et al., 2009) and 78.26\% (Borges et al., 2012), which are close to those determined in the present study.

According to the $\mathrm{F}$ test, the results obtained showed significant interaction $(\mathrm{p} \leq 0.05)$ regarding the effects of different drying processes and temperatures on the effective drying time variable, which is the total drying time excluding the tempering time. Table 1 presents a comparison of the means of the effective drying time for each temperature according to Tukey's test at $\mathrm{p} \leq 0.05$

As shown in Table 1, a significant reduction was noted in the effective drying time for the treatments at $50{ }^{\circ} \mathrm{C}$, with the
Table 1. Effective drying time (min) of O. gratissimum leaves subjected to continuous and intermittent drying at different temperatures

\begin{tabular}{|c|c|c|c|}
\hline \multirow{2}{*}{$\begin{array}{c}\text { Drying } \\
\text { processes }\end{array}$} & \multicolumn{3}{|c|}{ Temperature $\left({ }^{\circ} \mathrm{C}\right)$} \\
\hline & 50 & 60 & 70 \\
\hline Continuous drying & $158.33 \mathrm{a}$ & $61.67 \mathrm{a}$ & $46.67 \mathrm{a}$ \\
\hline Intermittent drying, 10/20 & $98.33 \mathrm{C}$ & $51.67 \mathrm{~b}$ & $30.00 \mathrm{~b}$ \\
\hline Intermittent drying, 15/15 & $153.33 \mathrm{a}$ & $56.67 \mathrm{ab}$ & $45.00 \mathrm{a}$ \\
\hline Intermittent drying, 20/10 & $130.00 \mathrm{~b}$ & $56.67 \mathrm{ab}$ & $41.67 \mathrm{a}$ \\
\hline LSD & & 8.60 & \\
\hline CV (\%) & & 4.93 & \\
\hline
\end{tabular}

intermittent ratios of $20 / 10$ and $10 / 20$; that of $10 / 20$ presented the shortest time, at $98.33 \mathrm{~min}$. Significant reductions in the effective drying time were also observed for the intermittent ratio of $10 / 20$ at temperatures of 60 and $70{ }^{\circ} \mathrm{C}$.

These data demonstrate that the longer tempering time applied in treatments with 10/20 intermittence resulted in a greater reduction in the effective drying time. This occurred because during the tempering period, the water is transferred from the center to the surface of the product, which facilitates its removal when the drying process is resumed (Kumar et al., 2014). Thus, the longer tempering period in these treatments caused a greater amount of water to be transferred to the leaf surface, which increased the drying rate in the post-tempering period.

Figures $1 \mathrm{~A}, \mathrm{~B}$ and $\mathrm{C}$ present the reduction in moisture content as a function of effective drying time for the drying of $O$. gratissimum leaves at 70,60 and $50{ }^{\circ} \mathrm{C}$, respectively. A comparison between the drying curve of the $10 / 20$ intermittent ratio and the continuous drying curve revealed that the intermittence of 10/20 contributed significantly to the moisture reduction in the samples throughout the drying process at all temperatures.

The $\mathrm{F}$ test $(\mathrm{p} \leq 0.05)$ also showed significant interaction of the different drying conditions according to specific energy consumption values. Table 2 presents a comparison of the means of the specific energy consumption for each temperature.

The Table 2 indicates that at a drying temperature of $50{ }^{\circ} \mathrm{C}$, the intermittent drying data showed a reduction in the specific energy consumption compared with that for continuous drying. The greatest reduction, $37.74 \%$, was observed with an intermittent ratio of $10 / 20$. The drying processes with intermittent ratios of $15 / 15$ and $20 / 10$ reduced the energy consumption 21.81 and $16.04 \%$, respectively. At $60{ }^{\circ} \mathrm{C}$, no significant differences in the specific energy consumption were noted among the treatments. At temperature of 70 ${ }^{\circ} \mathrm{C}$, the lowest specific energy consumption was noted at an intermittent ratio of $10 / 20$, which resulted in a reduction of $40.65 \%$ compared with that for continuous drying.

The lowest specific energy consumption for the treatments with an intermittence ratio of $10 / 20$ at temperatures of $50{ }^{\circ} \mathrm{C}$ and $70^{\circ} \mathrm{C}$ is attributed to the reduction in effective drying time when the intermittence was applied.

The results showed significant interaction by the $\mathrm{F}$ test ( $p \leq 0.05)$ for the effects of different drying conditions and 


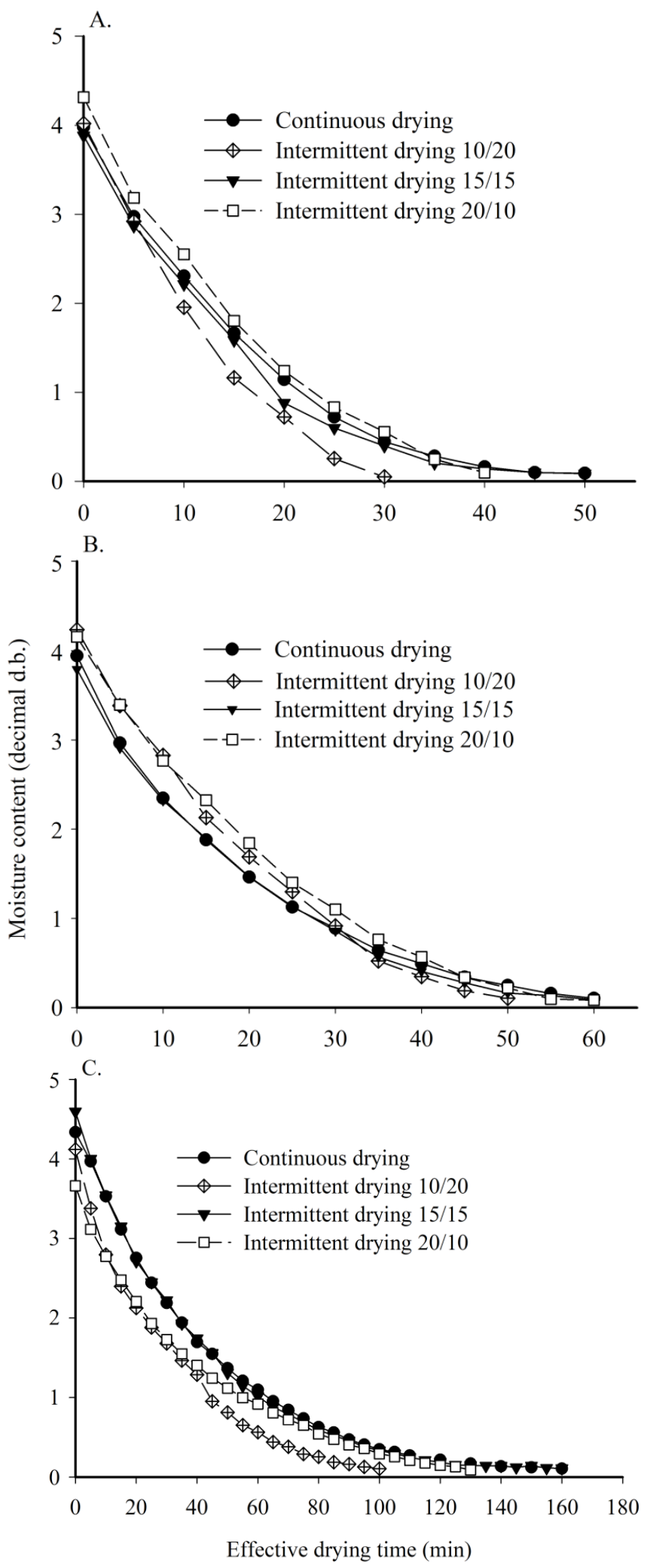

10/20, 15/15, 20/10 - Drying/tempering ratios in minutes

Figure 1. Moisture content as a function of effective drying time for drying O. grassimum leaves at (A) $70{ }^{\circ} \mathrm{C}$, (B) $60{ }^{\circ} \mathrm{C}$ and (C) $50{ }^{\circ} \mathrm{C}$

temperatures on the essential oil yield. A comparison of the means for each temperature, as shown in Figure 2.

The Figure 2 indicates that continuous drying at $50^{\circ} \mathrm{C}$ showed the highest essential oil yield, which could be related to the number of cycles (drying + tempering periods) for the treatments at this temperature. At lower drying air temperatures, an increase was
Table 2. Specific energy consumption ( $\mathrm{MJ} \mathrm{kg}^{-1}$ of evaporated water) obtained for each drying process at different temperatures

\begin{tabular}{lccc|}
\hline \multicolumn{1}{c}{ Drying } & \multicolumn{3}{c|}{ Temperature ( $\left.{ }^{\circ} \mathbf{C}\right)$} \\
\cline { 2 - 4 } processes & $\mathbf{5 0}$ & $\mathbf{6 0}$ & $\mathbf{7 0}$ \\
\hline Continuous drying & $141.92 \mathrm{a}$ & $75.72 \mathrm{a}$ & $78.33 \mathrm{a}$ \\
Intermittent drying, 10/20 & $88.36 \mathrm{C}$ & $65.45 \mathrm{a}$ & $46.49 \mathrm{~b}$ \\
Intermittent drying, 15/15 & $110.97 \mathrm{~b}$ & $72.17 \mathrm{a}$ & $65.45 \mathrm{a}$ \\
Intermittent drying, 20/10 & $119.16 \mathrm{~b}$ & $74.35 \mathrm{a}$ & $67.51 \mathrm{a}$ \\
LSD & & 11.43 & \\
CV (\%) & & 6.03 & \\
\hline
\end{tabular}

$10 / 20,15 / 15,20 / 10$ - Drying/tempering ratios in minutes; LSD - Least significant difference; CV - Coefficient of variation; Means followed by the same lowercase letter in the column do not differ from each other according to Tukey's test $(p>0.05)$

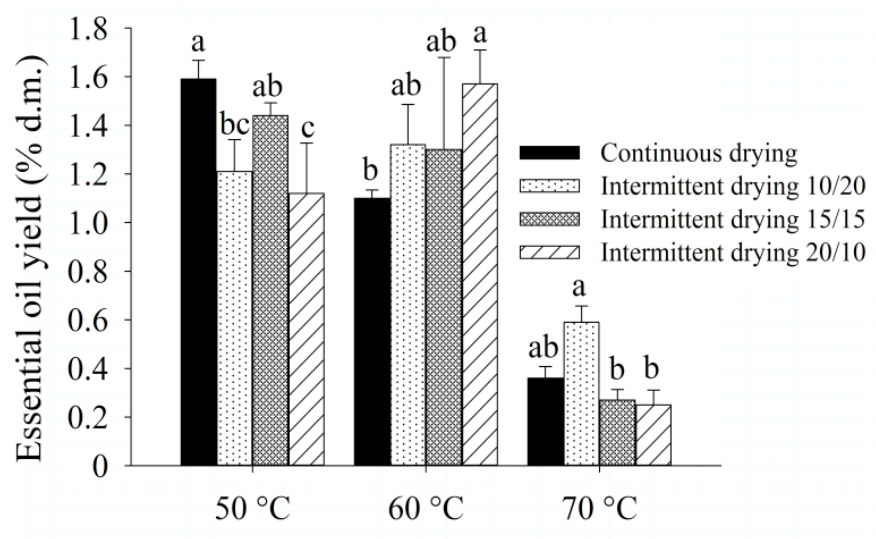

Drying temperature

$10 / 20,15 / 15,20 / 10$ - Drying/tempering ratios in minutes; Coefficient of variation = 13.16\%; Error bars represent the standard deviation of the means; Means followed by the same letter in each bar group do not differ from each other by Tukey's test at $\mathrm{p} \leq 0.05$ Figure 2. Essential oil yield of O. gratissimum leaves subjected to different drying processes and temperatures

noted in the time required for a sample to reach the predetermined moisture content. Thus, at $50{ }^{\circ} \mathrm{C}$, the number of cycles was greater than that needed at other temperatures studied (Table 3 ). Therefore, it can be assumed that at a temperature of $50^{\circ} \mathrm{C}$, the greater number of cycles caused damage to the leaves by creating thermal shock in the cellular tissues. The cells likely ruptured, which caused a loss of essential oil by volatilization during the drying processes subsequent to the tempering periods.

Another hypothesis is that during the tempering periods, the remaining heat in the leaves would have caused the essential

Table 3. Total and effective drying time and number of cycles for each treatment

\begin{tabular}{|c|c|c|c|c|}
\hline \multirow{2}{*}{$\begin{array}{l}\text { Drying } \\
\text { process }\end{array}$} & \multirow{2}{*}{$\begin{array}{l}\text { Temp. } \\
\left.\text { ( }{ }^{\circ} \mathrm{C}\right)\end{array}$} & \multicolumn{2}{|c|}{$\begin{array}{l}\text { Time required } \\
\text { for drying (min) }\end{array}$} & \multirow{2}{*}{$\begin{array}{c}\text { Cycle } \\
\text { (drying + tempering } \\
\text { period)* }\end{array}$} \\
\hline & & Total & Effective & \\
\hline Continuous drying & 50 & 160.00 & 160.00 & - \\
\hline Intermittent drying, 10/20 & 50 & 280.00 & 98.33 & 9.33 \\
\hline Intermittent drying, 15/15 & 50 & 280.00 & 153.33 & 9.33 \\
\hline Intermittent drying, 20/10 & 50 & 190.00 & 130.00 & 6.33 \\
\hline Continuous drying & 60 & 61.67 & 61.67 & - \\
\hline Intermittent drying, 10/20 & 60 & 142.50 & 51.67 & 4.75 \\
\hline Intermittent drying, $15 / 15$ & 60 & 115.00 & 56.67 & 3.83 \\
\hline Intermittent drying, 20/10 & 60 & 76.66 & 56.67 & 2.56 \\
\hline Continuous drying & 70 & 46.67 & 46.67 & - \\
\hline Intermittent drying, $10 / 20$ & 70 & 80.00 & 30.00 & 2.67 \\
\hline Intermittent drying, $15 / 15$ & 70 & 80.00 & 45.00 & 2.67 \\
\hline Intermittent drying, 20/10 & 70 & 80.00 & 41.67 & 2.67 \\
\hline
\end{tabular}

"These values refer to the end of the drying period before the last cycle was completed; $10 / 20,15 / 15,20 / 10$ - Drying/tempering ratios in minutes 
oil to volatilize. In a previous study that evaluated the effect of intermittence on the drying of yerba mate, a $10 \%$ loss of caffeine content was noted in the product samples with intermittent drying compared with that for continuous drying (Ramallo et al., 2010). The authors of that study also attributed this loss to the application of tempering periods in intermittent drying.

At $60{ }^{\circ} \mathrm{C}$, the results of the essential oil yield were different from those obtained for drying at $50^{\circ} \mathrm{C}$. At this temperature, no statistical differences were shown between continuous drying and intermittent drying of $10 / 20$ and $15 / 15$. Although the intermittence was detrimental during the drying experiments at a temperature of $50{ }^{\circ} \mathrm{C}$, the number of cycles was much lower at that of $60{ }^{\circ} \mathrm{C}$, which reduced the damage in the cellular structures and thus the loss of essential oil (Table 3 ). No justification was found for the effect of the 20/10 ratio on increasing the essential oil yield at that temperature.

At $70^{\circ} \mathrm{C}$ the intermittent ratio of $10 / 20$ provided the highest yield of essential oil. This result is attributed to the reduction in effective drying time with intermittent application. Thus, at the highest temperature, the shorter time of heat application minimized the loss of essential oil by volatilization.
The effect of drying temperature on the effective drying time, specific consumption of energy and essential oil yield for each treatment was analyzed by regression, as shown in Figures 3A, B and C, respectively.

For the effective drying time, all treatments presented adjustment to a polynomial regression model of the second degree. The regression coefficients for continuous drying and that applying the $15 / 15$ intermittent ratio did not differ statistically from each other ( $p>0.05)$; thus, these two treatments can be represented by the same equation (Figure $3 \mathrm{~A})$.

The results obtained indicate that an increase in drying air temperature promotes a reduction in the time required for the removal of water from O. gratissimum leaves for all drying conditions studied. These results also indicate that drying with an intermittent ratio of $10 / 20$ is the best treatment for reducing the effective drying time of $O$. gratissimum leaves for all temperatures studied.

The reduction in drying time as a function of drying air temperature increase is in accordance with the results obtained by several other researchers who studied the drying process
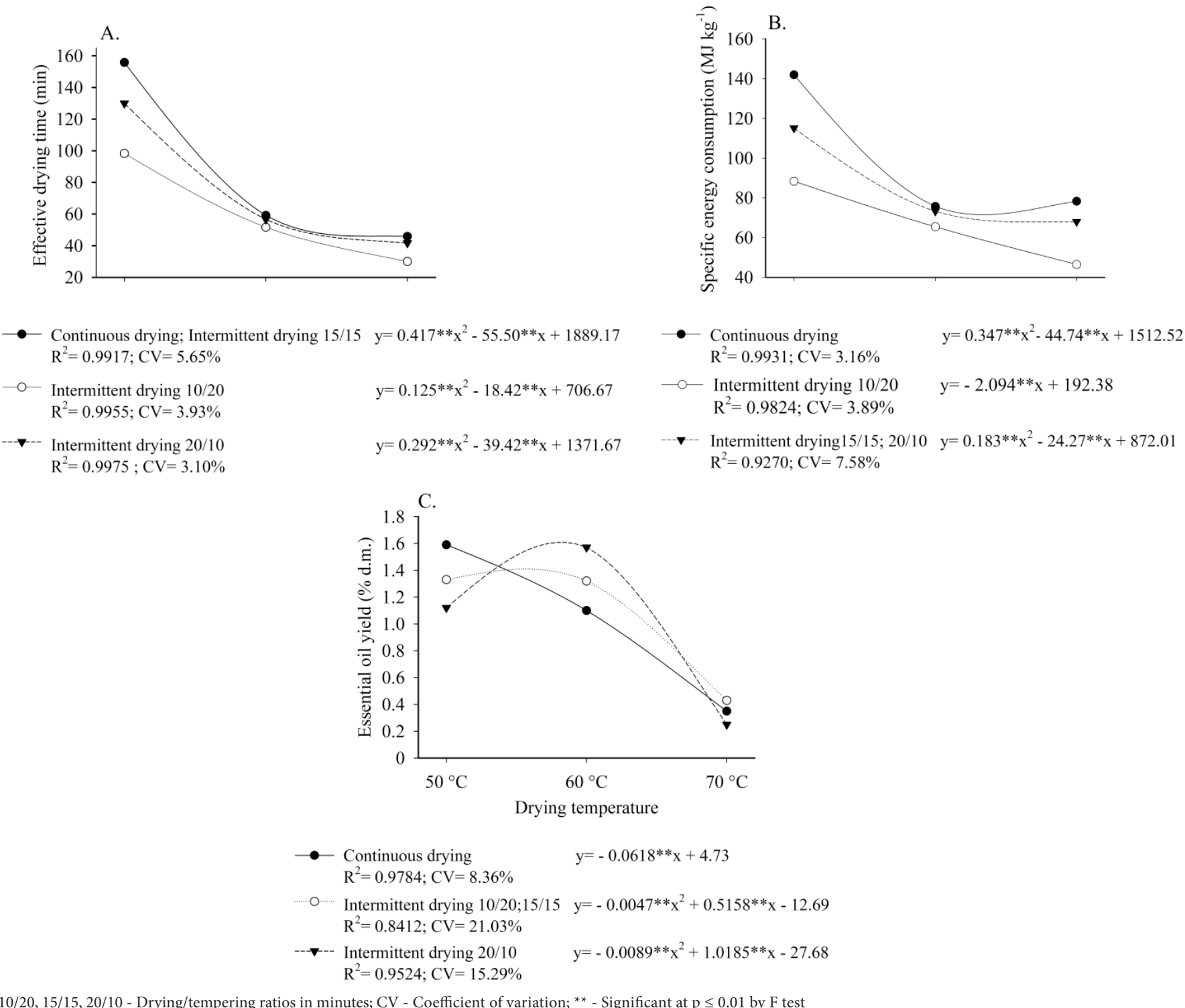

10/20, 15/15, 20/10 - Drying/tempering ratios in minutes; CV - Coefficient of variation; ${ }^{* *}$ - Significant at $\mathrm{p} \leq 0.01$ by F test

Figure 3. (A) Effective drying time, (B) specific energy consumption ( $\mathrm{MJ} \mathrm{kg}^{-1}$ of evaporated water) and (C) essential oil yield of $O$. gratissimum leaves as a function of drying temperature for each drying process 
of medicinal plant species (Goneli et al., 2014; Radünz et al., 2014; Gasparin et al., 2017).

The effect of drying temperature on specific energy consumption for each drying process is shown in Figure 3B. The treatments with $15 / 15$ and 20/10 intermittent ratios and with continuous drying showed an adjustment to a polynomial equation of the second degree. Because no significant differences were noted between the regression coefficients ( $p$ $>0.05$ ) of the data from intermittent ratio of $15 / 15$ and 20/10, these were adjusted for the same equation. The intermittent ratio of 10/20 fitted to a linear equation model.

The results for specific energy consumption showed increasing the drying air temperature from 50 to $60{ }^{\circ} \mathrm{C}$ improved the energy efficiency of the process. This fact is explained by the significant reduction in drying time with increases in drying air temperature. The effect of increasing the temperature from 60 to $70{ }^{\circ} \mathrm{C}$ was only perceptible for the intermittent ratio of $10 / 20$, which fitted to a linear regression equation model. For the other treatments, although the temperature of $70{ }^{\circ} \mathrm{C}$ reduced the drying time, it did not improve the energy efficiency of the process.

Figure 3C shows the effect of temperature on essential oil yield for each treatment. The treatments with continuous drying showed an adjustment to a linear equation model for the effect of drying temperature, whereas the intermittent treatments presented adjustment to a polynomial equation of the second degree. Because the regression coefficients for treatments with $10 / 20$ and 15/15 intermittent ratios did not differ statistically among them $(\mathrm{p}>0.05)$, they can be represented by the same equation.

As shown in Figure 3C, the yield of O. gratissimum essential oil decreased with an increase in temperature under continuous drying. A similar result was obtained in a previous study for the drying of the same species at temperatures of 30, 40, 50, and $60{ }^{\circ} \mathrm{C}$ (Santana et al., 2014). In that study, no significant difference was reported in the yield of essential oil extracted from the dry leaves at temperatures of 30,40 and $50{ }^{\circ} \mathrm{C}$. However, a $48 \%$ reduction in dry leaf content was reported at $60{ }^{\circ} \mathrm{C}$, which indicates a loss in volatile components after drying at this temperature. Another study investigated the influence of four drying air temperatures of 40, 50, 60 and 70 ${ }^{\circ} \mathrm{C}$ and two air velocities of 0.9 and $1.9 \mathrm{~m} \mathrm{~s}^{-1}$ on the essential oil yield of basil (Ocimum basilicum L.) (Soares et al., 2007). That study also reported a decrease in essential oil content with an increase in the drying temperature.

For intermittent treatments, the essential oil yield was lower at $50^{\circ} \mathrm{C}$, before increasing at $60^{\circ} \mathrm{C}$ and then decreasing at $70^{\circ} \mathrm{C}$.

\section{Conclusions}

1. Application of the $10 / 20$ intermittent ratio in the drying of $O$. gratissimum leaves efficiently reduces the effective drying time and specific energy consumption when using drying temperatures of 50 and $70{ }^{\circ} \mathrm{C}$.

2. The use of intermittence presented different results in the essential oil yield for each temperature of drying. For the optimal results in preserving the essential oil content in
O. gartissimum leaves, the use of tempering periods is not recommended at a temperature of $50^{\circ} \mathrm{C}$.

\section{ACKNOWLedgments}

This study was financed in part by the Coordenação de Aperfeiçoamento de Pessoal de Nível Superior - Brazil (CAPES) - Finance Code 001 and the Fundação de Amparo à Pesquisa do Estado de Minas Gerais (FAPEMIG) and the Conselho Nacional de Desenvolvimento Científico e Tecnológico (CNPq).

\section{Literature Cited}

Borges, A. M.; Pereira, J.; Cardoso, M. G.; Alves, J. A.; Lucena, E. M. P. Determinação de óleos essenciais de alfavaca (Ocimum gratissimum L.), orégano (Origanum vulgare L.) e tomilho (Thymus vulgaris L.). Revista Brasileira de Plantas Medicinais, v.14, p.656665, 2012. https://doi.org/10.1590/S1516-05722012000400013

Brasil. Farmacopéia brasileira. 5.ed. Brasília: ANVISA, 2010. 546p.

Chakraborty, R.; Dey, T. Drying protocols for traditional medicinal herbs: A critical review. International Journal of Engineering Technology, v.4, p.312-319, 2016.

Esturk, O. Intermittent and continuous microwave-convective airdrying characteristics of sage (Salvia officinalis) leaves. Food and Bioprocess Technology, v.5, p.1664-1673, 2012. https://doi. org/10.1007/s11947-010-0462-x

Gasparin, P. P.; Christ, D.; Coelho, S. R. M. Secagem de folhas Mentha piperita em leito fixo utilizando diferentes temperaturas e velocidades de ar. Revista Ciência Agronômica, v.48, p.242-250, 2017.

Goneli, A. L. D.; Nasu, A. K.; Gancedo, R.; Araújo, W. D.; Sarath, K. L. L. Cinética de secagem de folhas de erva baleeira (Cordia verbenacea DC.). Revista Brasileira de Plantas Medicinais, v.16, p.434-443, 2014. https://doi.org/10.1590/1983-084X/13_041

Kowalski, S. J.; Pawłowski, A. Energy consumption and quality aspect by intermittent drying. Chemical Engineering and Processing: Process Intensification, v.50, p.384-390, 2011. https://doi. org/10.1016/j.cep.2011.02.012

Kumar, C.; Karim, M. A.; Joardder, M. U. Intermittent drying of food products: A critical review. Journal of Food Engineering, v.121, p.48-57, 2014. https://doi.org/10.1016/j.jfoodeng.2013.08.014

Luz, J. M. Q.; Ehlert, P. A. D.; Innecco, R. Horário de colheita e tempo de secagem da alfavaca-cravo. Horticultura Brasileira, v.27, p.539542, 2009. https://doi.org/10.1590/S0102-05362009000400022

Marchese, J. A.; Figueira, G. M. O uso de tecnologias pré e pós-colheita e boas práticas agrícolas na produção de plantas medicinais e aromáticas. Revista Brasileira de Plantas Medicinais, v.7, p.86-96, 2005.

Okoduwa, S. I.; Umar, I. A.; James, D. B.; Inuwa, H. M. Anti-diabetic potential of Ocimum gratissimum leaf fractions in fortified diet-fed streptozotocin treated rat model of type- 2 diabetes. Medicines, v.4, p.1-21, 2017. https://doi.org/10.3390/medicines4040073

Onajobi, F. D. Smooth muscle contracting lipidic soluble principle in chromatographic functions of Ocimum gratissimum. Journal of Ethnopharmacolog, v.18, p.3-11, 1986. https://doi. org/10.1016/0378-8741(86)90038-3

Paula-Freire, L. I. G. D.; Andersen, M. L.; Molska, G. R.; Köhn, D. O.; Carlini, E. L. A. Evaluation of the antinociceptive activity of Ocimum gratissimum L. (Lamiaceae) essential oil and its isolated active principles in mice. Phytotherapy Research, v.27, p.12201224, 2013. https://doi.org/10.1002/ptr.4845 
Prakash, B.; Shukla, R.; Singh, P.; Mishra, P. K.; Dubey, N. K.; Kharwar, R. N. Efficacy of chemically characterized Ocimum gratissimum L. essential oil as an antioxidant and a safe plant based antimicrobial against fungal and aflatoxin B1 contamination of spices. Food Research International, v.44, p.385-390, 2011. https://doi.org/10.1016/j. foodres.2010.10.002

Putranto, A.; Chen, X. D.; Devahastin, S.; Xiao, Z.; Webley, P. A. Application of the reaction engineering approach (REA) for modeling intermittent drying under time-varying humidity and temperature. Chemical Engineering Science, v.66, p.2149-2156, 2011. https://doi.org/10.1016/j.ces.2011.02.025

Radünz, L. L.; Melo, E. C.; Rocha, R. P.; Barbosa, F. F.; Santos, R. H. S.; Berbet, P. A. Avaliação das curvas de secagem de guaco (Mikania glomerata Spreng.) em secador de bandejas. Revista Brasileira de Plantas Medicinais, v.16, p.378-387, 2014. https:// doi.org/10.1590/1983-084X/10_128
Ramallo, L. A.; Lovera, N. N.; Schmalko, M. E. Effect of the application of intermittent drying on Ilex paraguariensis quality and drying kinetics. Journal of Food Engineering, v.97, p.188-193, 2010. https://doi.org/10.1016/j.jfoodeng.2009.10.008

Saeio, K.; Chaiyana, W.; Okonogi, S. Antityrosinase and antioxidant activities of essential oils of edible Thai plants. Drug Discoveries \& Therapeutics, v.5, p.144-149, 2011. https://doi.org/10.5582/ ddt.2011.v5.3.144

Santana, A. C. M. D.; Pereira, G. S.; Boaventura, C. M.; Uetenabaro, A. P. T.; Costa, L. C. D. B.; Oliveira, R. A. D. Rupture of glandular trichomes in Ocimum gratissimum leaves influences the content of essential oil during the drying method. Revista Brasileira de Farmacognosia, v.24, p.524-530, 2014. https://doi.org/10.1016/j.bjp.2014.10.006

Soares, R. D.; Chaves, M. A.; Silva, A. A. L. D.; Silva, M. V. D.; Souza, B. D. S. Influência da temperatura e velocidade do ar na secagem de manjericão (Ocimum basilicum L.) com relação aos teores de óleos essenciais e de linalol. Ciência e Agrotecnologia, v.31, p.11081113, 2007. https://doi.org/10.1590/S1413-70542007000400025 